\title{
A New Species of Actinomycete, Amycolata alni
}

\author{
LYUDMILA I. EVTUSHENKO, V. N. AKIMOV, SVETLANA V. DOBRITSA, ${ }^{*}$ AND SVETLANA D. TAPTYKOVA \\ All-Union Collection of Microorganisms, Institute of Biochemistry and Physiology of Microorganisms, USSR Academy of \\ Sciences, Pushchino, Moscow Region, 142292, USSR
}

\begin{abstract}
A new species of the genus Amycolata, Amycolata alni, is proposed for strains which were mostly isolated from root nodules and rhizospheres of alder trees and were formerly assigned to the species Amycolata autotrophica. Strains of this new species could be differentiated from representatives of $A$. autotrophica by deoxyribonucleic acid homology data (17 to $29 \%$ relatedness), as well as by their ability to grow on salicin and D-gluconate, their failure to produce acid from cellobiose and meso-inositol, their resistance to penicillin and carbenicillin $(10 \mu \mathrm{g} / \mathrm{ml})$, and other characteristics. Phenotypic features and low levels of deoxyribonucleic acid homology distinguish A. alni from two other species of the genus Amycolata, Amycolata saturnea and Amycolata hydrocarbonoxydans. The type strain of A. alni is strain 3LS (= VKM Ac-901).
\end{abstract}

Eleven phenotypically similar nocardioform actinomycetes having a type IV cell wall composition and lacking mycolic acids were isolated from nitrogen-fixing root nodules and rhizospheres of two alder species, Alnus glutinosa and Alnus incana (29; L. S. Sharaya, Diss. C. Sci. thesis, Institute of Biochemistry and Physiology of Microorganisms, Pushchino, USSR, 1985). According to the identification keys and species descriptions that were available at that time $(3,14,15)$, these isolates were assigned to the species Nocardia autotrophica (20; Y. B. Malishkaite, Diss. C. Sci. thesis, University of Moscow, Moscow, USSR, 1984). Recently, $N$. autotrophica was included as the type species in the genus Amycolata, which was proposed, along with the genus Amycolatopsis, to accommodate nocardioform actinomycetes having cell wall chemotype IV and lacking mycolic acids (19). Besides the type strain, strain ATCC 19727, the description of Amycolata autotrophica included 28 strains of various origins assigned to $N$. autotrophica by Gordon et al. (14). Many physiological characteristics exhibited by these 28 strains are variable or different from those of the type strain (19), thus indicating that the species Amycolata autotrophica may be a heterogeneous taxon.

Variations in deoxyribonucleic acid (DNA) guanine-pluscytosine $(\mathrm{G}+\mathrm{C})$ ratios $(60$ to $72 \mathrm{~mol} \%)$ and DNA homology values (37 to 67\%) (24) among five strains from the group studied by Gordon et al. (14) have shown that strains of different genospecies may have been placed in Amycolata autotrophica primarily on the basis of physiological criteria. Recently, genetic heterogeneity among strains assigned to Amycolata autotrophica, including the strains from alder associations, was demonstrated by restriction fragment analysis of total genomic DNAs (10). These data showed that the alder isolates are distantly related to the type strain of Amycolata autotrophica.

Because of the obvious differences in genome structure among strains of the same species, as well as the abovementioned physiological variations, we compared strains assigned to Amycolata autotrophica more extensively. On the basis of DNA-DNA hybridization data and chemotaxonomic and physiological characteristics, we propose a new species, Amycolata alni, for $\mathbf{1 4}$ of the strains tested, including all 11 isolates from root nodules and rhizospheres of alders.

(Some of the data have been presented elsewhere [V. N.

\footnotetext{
* Corresponding author.
}

Akimov, S. V. Dobritsa, L. I. Evtushenko, and P. A. Shary, Abstr. 2nd Conf. Taxon. Automatic Identification Bacteria, Prague, Czechoslovakia, 1987].)

\section{MATERIALS AND METHODS}

Bacterial strains. The organisms used in this study are listed in Table 1. All of the strains assigned by us to Amycolata alni were originally received as Amycolata autotrophica strains. The type strain of Amycolata autotrophica was included in our work as two separate cultures (cultures DSM $535^{\mathrm{T}}$ and RIA $1008^{\mathrm{T}}$ ). Since these two cultures exhibited indistinguishable phenotypic characteristics and $100 \%$ DNA homology, as well as identical restriction banding patterns of their total genomic DNAs (10) and the same plasmid profiles (Dobritsa, unpublished data), we refer to only one of them below, strain DSM $535^{\mathrm{T}}(\mathrm{T}=$ type strain).

Morphology. Morphological characteristics were observed by phase-contrast microscopy of either living cultures or cultures prepared by the technique of Okami and Suzuki (25), which were fixed with a glacial acetic acid-ethanolchloroform mixture $(1: 6: 3)$ and then treated with tannin and finally stained with a $0.2 \%$ crystal violet solution. For microscopy, we used 3-, 7-, or 14-day-old cultures grown on either peptone-yeast extract agar (peptone, $5 \mathrm{~g}$; yeast extract, $3 \mathrm{~g} ;$ glucose, $5 \mathrm{~g} ; \mathrm{K}_{2} \mathrm{HPO}_{4}, 0.2 \mathrm{~g}$; distilled water, 1 liter; agar, $15 \mathrm{~g}$ ) or water agar supplemented with $0.1 \%$ casein hydrolysate.

Physiology. Physiological characteristics were studied by using previously described procedures $(13,15,16,27)$. Utilization of amino acids was determined in glucose-asparagine medium (glucose, $10 \mathrm{~g}$; L-asparagine, $0.5 \mathrm{~g} ; \mathrm{K}_{2} \mathrm{HPO}_{4}$, $0.5 \mathrm{~g}$; distilled water, 1 liter; $\mathrm{pH} 6.8$ ) with a corresponding amino acid substituted for asparagine. Susceptibility to certain concentrations of growth inhibitors and antibiotics was checked on peptone-yeast extract agar. For some antibiotics, minimal inhibitory concentrations were determined by the agar dilution method (12), using Mueller-Hinton agar (Difco Laboratories, Detroit, Mich.).

Cultural characteristics were observed on the media used for physiological tests.

Cell chemistry. Cell wall peptidoglycan preparations were obtained by the method of Schleifer and Kandler (28) and were further purified of proteins by boiling with $2 \%$ sodium dodecyl sulfate. The amino acid composition of a peptidoglycan was determined by using a Biotronik model LC 6000 E amino acid analyzer. 
TABLE 1. List of strains used ${ }^{a}$

\begin{tabular}{|c|c|c|}
\hline Strain designation as received & Other strain designation(s) & Received from: \\
\hline \multicolumn{3}{|l|}{ Strains assigned by us to Amycolata alni } \\
\hline $3 \mathrm{LS}^{\mathrm{T}}$ & VKM Ac- $901^{\mathrm{T}}$ & Sharaya \\
\hline $6 \mathrm{LS}$ & VKM Ac-914 & Sharaya \\
\hline $10 \mathrm{LS}$ & & Sharaya \\
\hline $11 \mathrm{LS}$ & VKM Ac-915 & Sharaya \\
\hline $12 \mathrm{LS}$ & & Sharaya \\
\hline $14 \mathrm{LS}$ & & Sharaya \\
\hline 19LS & & Sharaya \\
\hline $23 \mathrm{LS}$ & & Sharaya \\
\hline $24 \mathrm{LS}$ & VKM Ac-916 & Sharaya \\
\hline $25 \mathrm{LS}$ & & Sharaya \\
\hline 26LS & VKM Ac-917 & Sharaya \\
\hline VKM Ac-759 & & VKM \\
\hline VKM Ac-1066 & NCIB 8939, IMRU 1337 & VKM \\
\hline VKM Ac- $813^{b}$ & & VKM \\
\hline \multicolumn{3}{|l|}{ Reference and other strains } \\
\hline Amycolata autotrophica DSM $535^{\mathrm{T}}$ & ATCC $19727^{\mathrm{T}}$, VKM Ac-941 & Schlegel \\
\hline Amycolata autotrophica RIA $1008^{\mathrm{T}}$ & ATCC $19727^{\mathrm{T}}$ & RIA \\
\hline Amycolata autotrophica VKM Ac- 1065 & DSM 43103, IMRU 1577 & VKM \\
\hline Amycolata autotrophica VKM Ac- 1067 & JCM 4010 & VKM \\
\hline Amycolata autotrophica VKM Ac- 1068 & DSM 43098, IMRU 1398 & VKM \\
\hline Amycolata saturnea VKM Ac- $781^{\mathrm{T}}$ & ATCC $15809^{\mathrm{T}}$ & VKM \\
\hline Amycolata hydrocarbonoxydans VKM Ac- $799^{T}$ & ATCC $15104^{T}$ & VKM \\
\hline Micrococcus luteus $\mathrm{VKM} \mathrm{B-1314^{ \textrm {T } }}$ & $\operatorname{ATCC} 15307^{\mathrm{T}}$ & VKM \\
\hline
\end{tabular}

${ }^{a}$ Strains with designations ending in LS are isolates from alder associations. ATCC, American Type Culture Collection, Rockville, Md.; DSM, Deutsche Sammlung von Mikroorganismen, Göttingen, Federal Republic of Germany; IMRU, Waksman Institute of Microbiology, Rutgers, The State University of New Jersey, New Brunswick; JCM, Japan Collection of Microorganisms, Saitama, Japan; NCIB, National Collection of Industrial Bacteria, Aberdeen, United Kingdom; RIA, All-Union Research Institute for Antibiotics, Moscow, USSR; VKM, All-Union Collection of Microorganisms, Pushchino, USSR; Schlegel, H. G. Schlegel, Institut für Mikrobiologie, Universität Göttingen, Göttingen, Federal Republic of Germany; Sharaya, L. S. Sharaya, All-Union Collection of Microorganisms, Pushchino, USSR.

$b$ Strain VKM Ac-813 is a subculture from strain NCIB 8939 (= VKM Ac-1066), which was found to have lost a small plasmid (Dobritsa, unpublished data).

Cellular fatty acid methyl ethers were prepared by heating 40 to $50 \mathrm{mg}$ of a lyophilized biomass in a mixture containing $200 \mu \mathrm{l}$ of methanol and $50 \mu \mathrm{l}$ of acetyl chloride at $85^{\circ} \mathrm{C}$ until the reagents were completely evaporated. The methyl ethers were extracted with $n$-hexane and were analyzed by using a Perkin-Elmer model 3500 gas-liquid chromatograph equipped with a flame ionization detector and a type SE-30 capillary column.

Menaquinones were extracted and purified by the method of Collins and Jones (6), and their compositions were determined by using a model MX-1310 mass spectrometer. Phospholipids were isolated, analyzed by thin-layer chromatography, and identified by using the methods of Minnikin et al. (23). Phosphatidylcholine was identified with the Dragendorff reagent (17).

DNA base composition and DNA-DNA hybridization. Highmolecular-weight DNA was prepared as described previously (9) or by the technique of Bradley et al. (2), with some modifications. The $\mathrm{G}+\mathrm{C}$ content of the DNA was determined from its thermal denaturation midpoint (21) in $0.1 \times$ SSC $(1 \times S S C$ is $0.15 \mathrm{M} \mathrm{NaCl}$ plus $0.015 \mathrm{M}$ sodium citrate, $\mathrm{pH}$ 7.0) by using a Beckman model DU-8B spectrophotometer equipped with a thermoprogrammer. DNA base composition was calculated from the equation given by Owen and Pitcher (26), modified for another reference DNA. DNA from Micrococcus luteus VKM B-1314 ${ }^{\mathrm{T}}$, which contains 72 mol\% $\mathrm{G}+\mathrm{C}(21)$, was used as the reference.

The extent of DNA homology was determined by the membrane filter method, as modified by Meyer and Schleifer (22) and Stackebrandt et al. (30). ${ }^{3} \mathrm{H}$-labeled DNA was obtained by in vitro nick translation, using a type N.5000 nick translation kit (Radiochemical Centre, Amersham, United Kingdom) and deoxy $\left[{ }^{3} \mathrm{H}\right]$ cytidine 5'-triphosphate.
The radioactivities of the DNA preparations ranged from $10^{4}$ to $10^{5} \mathrm{cpm} / \mu \mathrm{g}$. A 0.1 - to $0.2-\mu \mathrm{g}$ portion of fragmented, denatured $\left[{ }^{3} \mathrm{H}\right] \mathrm{DNA}$ was incubated with a filter (type BA-85; diameter, $5.5 \mathrm{~mm}$; Schleicher \& Schuell, Dassel, Federal Republic of Germany) loaded with 7 to $10 \mu \mathrm{g}$ of unlabeled DNA in $200 \mu \mathrm{l}$ of $3 \times \mathrm{SSC}$ containing $35 \%$ formamide at $60^{\circ} \mathrm{C}$ for $24 \mathrm{~h}$. The amount of filter-fixed DNA was estimated by the method of Burton (4) after the radioactivity was counted and the filter was washed with toluene.

\section{RESULTS}

Morphology. The morphological properties of some of the strains received by us as Amycolata autotrophica have been studied and described in detail previously $(1,14,18,19,29)$. In particular, the strains isolated from alder associations were characterized by their ability to divide swollen hyphal fragments in transverse and longitudinal planes $(1,18,29)$, which has never been reported previously for Amycolata autotrophica. Thus, the purpose of this study was to compare the morphological characteristics of the alder isolates with those of the type strain of Amycolata autotrophica grown under the same conditions. All of the strains examined were shown to have similar morphological properties which are characteristic of the group of nocardioform organisms. The cultures formed true mycelia with diameters of 0.5 to $1.5 \mu \mathrm{m}$ (sometimes up to $2 \mu \mathrm{m}$ ), which tended to break down into rod-shaped and oval elements after 2 to 4 days. Chains of spores were produced on both the substrate and aerial hyphae, with diameters somewhat larger than those of the hyphae. When living cultures were observed by phasecontrast microscopy, local hyphal thickenings up to 2 to 2.5 $\mu \mathrm{m}$ in diameter and of variable lengths (from 2 to $8 \mu \mathrm{m}$ and 
more) were detected in all of the strains, including strain DSM $535^{\mathrm{T}}$, although these thickenings were observed more often in fresh isolates than in strains stored in culture collections for a long time. In stained preparations, transverse and longitudinal septa were observed within these structures.

Cultural properties. The cultural characteristics of Amycolata autotrophica and Amycolata alni strains were similar, corresponding to those given in the description of Amycolata autotrophica (19). All of the strains produced aerial mycelia which were white to cream colored. However, the color of the substrate hyphae produced by a strain, especially on organic media, was very specific, so that the strains of Amycolata autotrophica produced orangish yellow vegetative mycelia, while the strains of Amycolata alni formed orangish brown to brown substrate mycelia.

Chemotaxonomic properties. A study of the sugar and amino acid compositions of six strains isolated from alder associations, together with the previous data on strain $3 \mathrm{LS}^{\mathrm{T}}$ (29), confirmed that all of the cultures had a type IV cell wall composition (meso-diaminopimelic acid, arabinose, and galactose). No mycolic acids were detected. The amino acid compositions of the peptidoglycans were similar in the cultures tested. The molar ratio of amino acids (ratio of alanine to glutamic acid to diaminopimelic acid) was about $2: 1: 1$, corresponding to the Al $\gamma$ peptidoglycan (28).

The principal menaquinone component in Amycolata autotrophica DSM $535^{\mathrm{T}}$ and Amycolata alni $3 \mathrm{LS} \mathrm{S}^{\mathrm{T}}$ and $6 \mathrm{LS}$ was a type MK-8 $\left(\mathrm{H}_{4}\right)$ menaquinone. Both strains of Amycolata autotrophica (DSM 535 and VKM Ac-1065) and strains of Amycolata alni (3LS ${ }^{\mathrm{T}}$, VKM Ac-759, and VKM Ac-1066) had type PIII phospholipid patterns (the diagnostic phospholipids are phosphatidylcholine and phosphatidylmethylethanolamine).

The fatty acid spectra of representative strains of Amycolata autotrophica and Amycolata alni contained 17 to 18 components in amounts of more than $0.2 \%$ (Table 2). The principal components were saturated branched-chain acids of the iso and anteiso types (14-methylpentadecanoic acid [iso-16:0 acid] and 14-methylhexadecanoic acid [anteiso-17:0 acid]). Straight-chain saturated fatty acids (15:0, 16:0, and 17:0 acids) and unsaturated fatty acids (hexadecenoic acid [16:1 acid] and 14-methyl-pentadecenoic acid [iso-16:1 acid]), as well as 10-methyl-branched fatty acids (10-methyl16:0 acid and 10-methyl-17:0 acid), were detected in amounts up to $10 \%$. Tuberculostearic acid (10-methyl-18:0 acid) was present in trace amounts (less than $0.2 \%$ ).

DNA base composition and DNA-DNA homology. The DNA $\mathrm{G}+\mathrm{C}$ contents ranged from 71 to $73.5 \mathrm{~mol} \%$ in the four Amycolata autotrophica strains and from 72 to $74 \mathrm{~mol} \%$ in the strains of Amycolata alni (Table 3). The DNAs from the strains of Amycolata alni shared only 17 to $29 \%$ homology with the DNAs from the strains of Amycolata autotrophica (Table 3). The levels of DNA homology among the strains of Amycolata autotrophica were 51 to $78 \%$, and the levels of DNA homology among the strains of Amycolata alni were 67 to $94 \%$. Strains of both species exhibited low levels of DNA relatedness (usually less than $18 \%$ ) to the type strains of Amycolata saturnea and Amycolata hydrocarbonoxydans (data not shown).

Physiology. More than 150 characteristics of the strains assigned to Amycolata alni and Amycolata autotrophica and the type strains of the two other Amycolata species were studied. On the whole, the 14 Amycolata alni strains were characterized, compared with the other organisms, by wider spectra of hydrolytic enzymes and utilizable carbon and
TABLE 2. Cellular fatty acid compositions of Amycolata autotrophica and Amycolata alni ${ }^{a}$

\begin{tabular}{lcc}
\hline & \multicolumn{2}{c}{$\%$ In: } \\
\cline { 2 - 3 } Fatty acid $^{b}$ & $\begin{array}{c}\text { Amycolata } \\
\text { autotrophica }\end{array}$ & $\begin{array}{c}\text { Amycolata } \\
\text { alni }\end{array}$ \\
\hline ai-14:0 & $0.3-0.8^{c}$ & $0.2-0.4$ \\
$14: 0$ & $0.1-0.3$ & $0.1-0.2$ \\
$\mathrm{i}-15: 0^{d}$ & $4.5-15.8$ & $1.6-3.7$ \\
ai-15:0 & & $0.8-9.5$ \\
$15: 1$ & $0.7-0.8$ & $0.3-1.6$ \\
$15: 0^{d}$ & $0.6-1.6$ & $1.4-2.6$ \\
$\mathrm{i}-16: 1$ & $5.0-6.8$ & $5.8-8.6$ \\
$\mathrm{i}-16: 0^{d}$ & $18.6-36.5$ & $36.2-39.6$ \\
$16: 1$ & $5.0-6.8$ & $5.8-8.6$ \\
$16: 0^{d}$ & $3.3-5.5$ & $5.8-8.1$ \\
$\mathrm{X}^{d}$ & $2.6-9.1$ & $0.5-1.7$ \\
Me-17:0 & $2.5-6.1$ & $2.7-5.8$ \\
$\mathrm{i}-17: 0$ & $2.8-8.5$ & $4.4-14.4$ \\
ai-17:0 $_{17: 0^{d}}$ & $13.6-15.2$ & $14.3-18.9$ \\
Me-18:0 $^{d}$ & $1.1 .-2.4$ & $4.5-9.6$ \\
ai-18:0 & $1.8-3.4$ & $3.5-6.9$ \\
$18: 0^{d}$ & $0.4-0.8$ & $1.2-7.5$ \\
Me-19:0 $^{d}$ & $0.2-0.3$ & $0.5-1.0$ \\
\hline
\end{tabular}

${ }^{a}$ The strains used were the strains listed in Table 3 ; in addition, Amycolata alni $26 \mathrm{LS}$ was included.

${ }^{b} \mathrm{i}$, iso; ai, anteiso; X, unidentified constituent; Me, 10-methyl-branched. The first number indicates the number of carbon atoms, and the second number indicates the number of double bonds.

$c$ Range expressed as percentage of the total amount.

${ }^{d}$ The relative amounts of these fatty acids are specific for each of the two species.

nitrogen sources, as well as lower susceptibility to growth inhibitors and antibiotics. A detailed characterization of those properties which were common to most strains of Amycolata alni is given below in the description of this species. A summary of differentiating characteristics for Amycolata spp. is presented in Table 4 .

\section{DISCUSSION}

Besides the type strain of Amycolata autotrophica (19, 31), this study included 11 strains isolated from root nodules and rhizospheres of alders (Sharaya, Diss. C. Sci. thesis) and four strains (strains VKM Ac-1065, VKM Ac-1068, VKM

TABLE 3. DNA base compositions and levels of DNA-DNA homology for Amycolata autotrophica and Amycolata alni strains

\begin{tabular}{|c|c|c|c|}
\hline \multirow[b]{2}{*}{ Organism } & \multirow{2}{*}{$\begin{array}{c}\mathrm{G}+\mathrm{C} \\
\text { content } \\
(\mathrm{mol} \%)\end{array}$} & \multicolumn{2}{|c|}{$\begin{array}{l}\text { \% Homology with labeled } \\
\text { DNA from: }\end{array}$} \\
\hline & & $\begin{array}{c}\text { Amycolata } \\
\text { autotrophica } \\
\text { DSM } 535^{\mathrm{T}}\end{array}$ & $\begin{array}{l}\text { Amycolata } \\
\text { alni } 3 \mathrm{LS}^{\mathrm{T}}\end{array}$ \\
\hline \multicolumn{4}{|c|}{ Amycolata autotrophica strains } \\
\hline DSM $535^{\mathrm{T}}$ & 72 & 100 & 21 \\
\hline VKM Ac-1067 & 72 & 78 & 17 \\
\hline VKM Ac-1068 & 71 & 51 & 24 \\
\hline VKM Ac-1065 & 73.5 & 55 & 29 \\
\hline \multicolumn{4}{|l|}{ Amycolata alni strains } \\
\hline $3 \mathrm{LS}^{\mathrm{T}}$ & 72 & 26 & 100 \\
\hline 6LS & 73 & 24 & 71 \\
\hline 11LS & 73 & 29 & 94 \\
\hline VKM Ac-759 & 74 & 24 & 67 \\
\hline VKM Ac-1066 & 73.5 & 23 & 88 \\
\hline VKM Ac-813 & 73 & 28 & 78 \\
\hline
\end{tabular}


TABLE 4. Differentiating characteristics of Amycolata spp.

\begin{tabular}{|c|c|c|c|c|}
\hline Characteristic & $\begin{array}{l}\text { Amycolata } \\
\text { autotrophica } \\
\text { (4 strains) }\end{array}$ & $\begin{array}{c}\text { Amycolata } \\
\text { saturnea } \\
\text { VKM Ac-781 }\end{array}$ & $\begin{array}{c}\text { Amycolata } \\
\text { hydrocarbonoxydans } \\
\text { VKM Ac- } 799^{\mathrm{T}}\end{array}$ & $\begin{array}{l}\text { Amycolata } \\
\text { alni sp. nov. } \\
\text { (14 strains) }\end{array}$ \\
\hline \multicolumn{5}{|l|}{ Decomposition of: } \\
\hline Adenine & $+^{a}$ & - & - & + \\
\hline Hypoxanthine & - & + & - & + \\
\hline Tyrosine & - & + & - & + \\
\hline Xanthine & - & + & - & V \\
\hline \multicolumn{5}{|l|}{ Decarboxylation of: } \\
\hline Benzoate & $\mathrm{V}$ & + & - & + \\
\hline Citrate & + & - & - & + \\
\hline \multicolumn{5}{|l|}{ Production of: } \\
\hline Amylase & - & - & + & + \\
\hline Urease & + & + & - & + \\
\hline Growth on $5 \% \mathrm{NaCl}$ & + & - & - & + \\
\hline \multicolumn{5}{|l|}{ Acid produced from: } \\
\hline Adonitol & + & - & - & + \\
\hline D-Cellobiose & + & + & + & - \\
\hline meso-Erythritol & + & - & + & + \\
\hline Galactose & + & - & + & + \\
\hline meso-Inositol & + & + & + & - \\
\hline D-Lactose & - & - & + & - \\
\hline D-Mannitol & + & + & - & + \\
\hline$\alpha$-Methyl-D-glucoside & $\mathrm{V}^{b}$ & + & - & V \\
\hline D-Salicin & - & - & + & + \\
\hline D-Sorbitol & $\mathrm{V}^{b}$ & - & - & + \\
\hline \multicolumn{5}{|l|}{ Growth on sole carbon sources } \\
\hline D-Gluconate & - & + & + & + \\
\hline$\alpha$-Methyl-D-glucoside & - & + & + & + \\
\hline meso-Inositol & + & + & + & - \\
\hline \multicolumn{5}{|l|}{ Utilization as nitrogen sources } \\
\hline L-Histidine & - & - & - & + \\
\hline L-Proline & V & + & - & + \\
\hline Resistance to carbenicillin $(10 \mu \mathrm{g} / \mathrm{ml})$ & - & - & - & + \\
\hline Color of substrate hyphae & Yellow to orange & Orange & Orange & Brown to orange \\
\hline
\end{tabular}

$a+$, Positive; - , negative; $\mathrm{V}$, variable.

$b$ The type strain is negative.

Ac-1066, and VKM Ac-813 [a derivative of strain VKM Ac-1066]) belonging to the group studied by Gordon et al. (14). We have no information about two other strains (strains VKM Ac-759 and VKM Ac-1067) except that they originated from the culture collections of A. Takamiya and A. Tubaki, respectively, who first described (31) the species Streptomyces autotrophicus (Amycolata autotrophica). Our study showed that morphologically and chemotaxonomically all of these strains constitute a homogeneous group. In all of them, including the type strain of Amycolata autotrophica (strain DSM 535), local hyphal thickenings with longitudinal and transverse septa, which were demonstrated previously in strain $3 \operatorname{LS}^{\mathbf{T}}(1,18,29)$, were observed at different frequencies. Evidently, the description of Amycolata autotrophica (19) should be supplemented by characterization of these structures.

The chemotaxonomic properties of all of the strains were shown to be similar and correspond to those of the genus Amycolata (19), as follows: meso-diaminopimelic acid, arabinose, and galactose in the cell wall, lack of mycolic acids, peptidoglycan $A 1 \gamma$, type PIII phospholipid pattern, and major menaquinones of the $\mathrm{MK}-8\left(\mathrm{H}_{4}\right)$ type. In accordance with the data of Collins et al. (5) reported for strains ATCC $19727^{\mathrm{T}}$ (= DSM 535 $)$ and NCIB 8939 (= VKM Ac-1066), we failed to detect in the strains which we tested type MK-8 $\left(\mathrm{H}_{2}\right)$ menaquinones, which are included in the description of Amycolata autotrophica (19). The fatty acid spectra of the strains which we studied were similar; however, differences in the relative amounts of some fatty acids (iso-15:0, 15:0, iso-16:0, 16:0, 17:0, methyl-18:0, anteiso-18:0, and 18:0 acids) were found between representative strains of Amycolata autotrophica and Amycolata alni.

The DNA base compositions of the strains which we examined ranged between 71 and $74 \mathrm{~mol} \% \mathrm{G}+\mathrm{C}$. Thus, the upper limit of the DNA G+C content for the genus Amycolata should be raised to $74 \mathrm{~mol} \%$ (rather than $71 \mathrm{~mol} \%$ [19]). The somewhat higher value ( 72 versus $70 \mathrm{~mol} \%$ ) obtained for the type strain of Amycolata autotrophica by us compared with the data reported by Lechevalier et al. (19) was probably due to the method of DNA isolation which we used (9), which yielded more intact DNA preparations.

Ten of the strains tested, which we received as Amycolata autotrophica, are divided into two groups on the basis of DNA-DNA hybridization data, which agrees with the results of a numerical taxonomic study (L. I. Evtushenko, L. G. Tomashevskaya, and P. A. Shary, Mikrobiologiya, in press). This shows that strains formerly assigned to Amycolata autotrophica represent at least two distinct species of the genus Amycolata. In this study, one of these species, Amycolata autotrophica, was represented by four strains, including type strain DSM 535, which displayed DNA-DNA homology levels ranging from 51 to $78 \%$ and formed a single cluster (Evtushenko et al., in press). The strains of another group constitute a separate taxospecies (Evtushenko et al., in press) and exhibit high degrees of DNA relatedness (67 to $94 \%$ ), corresponding to a single genospecies. The close genetic relatedness among some strains of the latter species was demonstrated by the identical or similar banding pat- 
terns of their genomic DNA restriction fragments $(10,11)$ and by the same plasmid composition (8). The members of this species have low levels of DNA homology with all Amycolata species described previously, cluster at some distance by numerical taxonomic analysis (Evtushenko et al., in press), and display a number of phenotypic characteristics which differentiate them from Amycolata autotrophica, Amycolata saturnea, and Amycolata hydrocarbonoxydans. Evidently, they represent a new species of the genus Amycolata, for which we propose the name Amycolata alni. Most strains of the new species (11 of 14 strains) were isolated from the rhizoplanes and rhizospheres of alders (Sharaya, Diss. C. Sci. thesis). Among them, strain 3LS (= VKM Ac-901) is the best-studied organism $(1,7,8$, 10, 11, 18, 20, 29; Malishkaite, Diss. C. Sci. thesis; Sharaya, Diss. C. Sci. thesis) and therefore is designated the type strain of Amycolata alni. Three other strains (strains VKM Ac-759, VKM Ac-1066, and VKM Ac-813 [a variant of strain VKM Ac-1066]) have been stored in culture collections for a long time, and strain VKM Ac-1066 (= NCIB 8939) is rather well studied $(5,14,15,24)$. Below is a description of the new species.

Amycolata alni sp. nov. Amycolata alni (al'ni. L.adj. alni, of Alnus, alder, referring to the isolation of the type strain and some other strains from alder associations). Substrate and aerial mycelia are formed; both fragment into rodshaped and oval elements. The aerial mycelium $(0.7$ to 1.0 $\mu \mathrm{m}$ wide) is white to cream colored, and the vegetative mycelium is orange to brown. Chains of spores (up to $1.5 \mu \mathrm{m}$ in diameter) are abundantly formed on the aerial hyphae. The vegetative hyphae are characterized by pronounced pleomorphisms, forming thickenings up to $2 \mu \mathrm{m}$ in diameter, as well as cells of a polygonal shape and their conglomerates. Formation of swollen hyphal segments (up to $2.5 \mu \mathrm{m}$ in diameter and up to $10 \mu \mathrm{m}$ long) with transverse and longitudinal septa is a characteristic trait.

Nitrate reductase, phosphatase, and urease are produced by most strains. Adenine, esculin, gelatin, hypoxanthine, starch, Tween 40, Tween 60, Tween 80, tyrosine, and xanthine are hydrolyzed. Allantoin, casein, and cellulose are not hydrolyzed. Acetate, aconitate, benzoate, citrate, formate, fumarate, $\alpha$-ketoglutarate, lactate, malate, maleate, propionate, pyruvate, sebacate, succinate, and trans-aconitate are utilized. Produces acid from and grows on adonitol, L-arabinose, meso-erythritol, D-fructose, galactose, D-glucose, glycerol, $\alpha$-methyl-D-glucoside, D-maltose, D-mannitol, L-ribose, D-salicin, D-sorbitol, DL-sucrose, trehalose, and D-xylose as sole carbon sources. Acid is produced from $\mathrm{D}$-arabinose, but growth is variable. No acid is formed from D-cellobiose, dulcitol, meso-inositol, D-lactose, D-mannose, melibiose, L-rhamnose, and D-sorbose. Grows on D-gluconate but not on D-glucuronate as a sole carbon source. Assimilates as nitrogen sources asparagine, glutamine, ornithine, arginine, leucine, proline, and histidine. Very weak growth on media containing other amino acids as sole nitrogen sources. Moderate growth on water agar.

Tolerates $7 \% \mathrm{NaCl}, 0.001 \%$ phenol, and $0.01 \%$ thymol. Susceptible to the following antibiotics: monomycin $(8 \mu \mathrm{g} /$ $\mathrm{ml})$, roseofungin $(10 \mu \mathrm{g} / \mathrm{ml})$, neomycin $(4 \mu \mathrm{g} / \mathrm{ml})$, fucidin $(10$ $\mu \mathrm{g} / \mathrm{ml})$, streptomycin $(4 \mu \mathrm{g} / \mathrm{ml})$, chloramphenicol $(32 \mu \mathrm{g} / \mathrm{ml})$, gentamicin $(4 \mu \mathrm{g} / \mathrm{ml})$, rifampin $(0.125 \mu \mathrm{g} / \mathrm{ml})$, kanamycin $(16$ $\mu \mathrm{g} / \mathrm{ml})$, and vancomycin $(0.5 \mu \mathrm{g} / \mathrm{ml})$. In contrast to Amycolata autotrophica, susceptible to nalidixic acid $(64 \mu \mathrm{g} / \mathrm{ml})$, novobiocin $(0.25 \mu \mathrm{g} / \mathrm{ml})$, and tetracycline $(1 \mu \mathrm{g} / \mathrm{ml})$ but resistant to ampicillin ( 1 to $16 \mu \mathrm{g} / \mathrm{ml})$, benzylpenicillin $(0.5$ to $10 \mu \mathrm{g} / \mathrm{ml})$, carbenicillin (1 to $10 \mu \mathrm{g} / \mathrm{ml})$, ristomycin $(0.05 \mu \mathrm{g} /$ $\mathrm{ml})$, tobramycin $(5 \mu \mathrm{g} / \mathrm{ml})$, and vancomycin $(0.25 \mu \mathrm{g} / \mathrm{ml})$. No growth in lysozyme broth $(50 \mu \mathrm{g} / \mathrm{ml})$.

The major fatty acids are the following saturated branched-chain acids of the iso and anteiso types: iso-16:0 acid (up to $40 \%$ ) and anteiso-17:0 acid (up to 20\%). 10methyl-17:0 and 10-methyl-18:0 acids, as well as tuberculostearic acid (traces), are also present. The principal menaquinone component is $\mathrm{MK}-8\left(\mathrm{H}_{4}\right)$. The $\mathrm{G}+\mathrm{C}$ content of the DNA is 72 to $74 \mathrm{~mol} \%$ (as determined by the thermal denaturation method).

Isolated from root nodules and rhizospheres of alders (Alnus glutinosa [L.] Gaertn. and Alnus incana [L.] Moench.), as well as from other sources.

The type strain is strain $3 \mathrm{LS}$ (= VKM Ac-901).

\section{ACKNOWLEDGMENTS}

We thank L. S. Sharaya for providing the alder isolates, V. M. Adanin for help in the analyses of the menaquinones, and V. Y. Ilchenko for assistance with the amino acid analyses.

\section{LITERATURE CITED}

1. Agre, N. S., V. P. Shekhovtsev, T. F. Kuimova, Y. B. Malishkaite, and L. S. Sharaya. 1984. Micromorphology and fine structure of the 3LS isolate. Actinomycetes 18:54-66.

2. Bradley, S. G., G. H. Brownell, and J. Clark. 1973. Genetic homologies among nocardiae and other actinomycetes. Can. J. Microbiol. 19:1007-1014.

3. Buchanan, R. E., and N. E. Gibbons (ed.). 1974. Bergey's manual of determinative bacteriology, 8th ed. The Williams \& Wilkins Co., Baltimore.

4. Burton, K. 1956. A study of the conditions and mechanism of the diphenylamine reaction for the colorimetric estimation of deoxyribonucleic acid. Biochem. J. 62:315-323.

5. Collins, M. D., M. Goodfellow, D. E. Minnikin, and G. Alderson. 1985. Menaquinone composition of mycolic acid-containing actinomycetes and some sporoactinomycetes. J. Appl. Bacteriol. 58:77-86.

6. Collins, M. D., and D. Jones. 1981. Distribution of isoprenoid quinone structural types in bacteria and their taxonomic implications. Microbiol. Rev. 45:316-354.

7. Dobritsa, S. V. 1982. Multiple antibiotic resistance of actinomycetes from root nodules and the rhizosphere of alder. Antibiotiki (Mosc.) 27:511-516. (In Russian.)

8. Dobritsa, S. V. 1984. Large plasmids in an actinomycete. FEMS Microbiol. Lett. 23:35-39.

9. Dobritsa, S. V. 1985. Restriction analysis of the Frankia spp. genome. FEMS Microbiol. Lett. 29:123-128.

10. Dobritsa, S. V. 1987. Restriction analysis of Nocardia autotrophica DNA. Mikrobiologiya 56:397-402. (In Russian.)

11. Dobritsa, S. V., and L. S. Sharaya. 1986. Genome identity of different Nocardia autotrophica isolates from Alnus spp. root nodules and rhizosphere, p. 735-737. In G. Szabó, S. Biró, and M. Goodfellow (ed.), Biological, biochemical and biomedical aspects of actinomycetes, part B. Akadémiai Kiadó, Budapest.

12. Ericsson, H. M., and J. C. Sherris. 1971. Antibiotic sensitivity testing. Report of an international collaborative study. Acta Pathol. Microbiol. Scand. Sect. B Suppl. 217:1-90.

13. Goodfellow, M. 1971. Numerical taxonomy of some nocardioform bacteria. J. Gen. Microbiol. 69:33-80.

14. Gordon, R. E., D. A. Barnett, J. E. Handerhan, and C. H.-N. Pang. 1974. Nocardia coeliaca, Nocardia autotrophica, and the nocardin strain. Int. J. Syst. Bacteriol. 24:54-63.

15. Gordon, R. E., S. K. Mishra, and D. A. Barnett. 1978. Some bits and pieces of the genus Nocardia: N. carnea, N. vaccinii, $N$. transvalensis, $N$. orientalis and $N$. aerocolonigenes. J. Gen. Microbiol. 109:69-78.

16. Jones, D. 1975. A numerical taxonomic study of coryneform and related bacteria. J. Gen. Microbiol. 87:52-96.

17. Kates, M. 1972. Techniques of lipidology. Isolation, analysis and identification of lipids. North-Holland Publishing Co., Amsterdam. 
18. Kuimova, T. F., and Y. B. Malishkaite. 1984. Fine structure characteristics of Nocardia autotrophica. Mikrobiologiya 53: 342-345. (In Russian.)

19. Lechevalier, M. P., H. Prauser, D. P. Labeda, and J.-S. Ruan. 1986. Two new genera of nocardioform actinomycetes: Amycolata gen. nov. and Amycolatopsis gen. nov. Int. J. Syst. Bacteriol. 36:29-37.

20. Malishkaite, Y. B., S. D. Taptykova, L. I. Evtushenko, V. M. Adanin, A. N. Pariiskaya, E. N. Disler, L. S. Sharaya, and N. S. Agre. 1984. Genus identification of actinomycetes isolated from root nodules of Alnus spp. and other non-leguminous plants. Biol. Nauki (Mosc.) 4:83-86. (In Russian.)

21. Marmur, J., and P. Doty. 1962. Determination of the base composition of deoxyribonucleic acid from its thermal denaturation temperature. J. Mol. Biol. 5:109-118.

22. Meyer, S. A., and K. H. Schleifer. 1978. Deoxyribonucleic acid reassociation in the classification of coagulase-positive staphylococci. Arch. Microbiol. 117:183-188.

23. Minnikin, D. E., A. G. O'Donnell, M. Goodfellow, G. Alderson, M. Athalye, A. Shaal, and J. H. Parlett. 1984. An integrated procedure for the extraction of bacterial isoprenoid quinones and polar lipids. J. Microbiol. Methods 2:233-241.

24. Mordarski, M., K. Szyba, A. Tkacz, and I. Kaszen. 1974 Comparison of DNA homology in Nocardia amarae, N. autotrophica and Rhodococcus strains. Actinomycetes 12:21-26.

25. Okami, Y., and M. Suzuki. 1958. A simple method for micro- scopical observation for streptomycetes and critique of Streptomyces grouping with reference to aerial structure. J. Antibiot. 11:250-253.

26. Owen, R. J., and D. Pitcher. 1985. Current methods for estimating DNA base composition and levels of DNA-DNA hybridization, p. 67-93. In M. Goodfellow and D. E. Minnikin (ed.), Chemical methods in bacterial systematics. Academic Press, Inc. (London), Ltd., London.

27. Pridham, T. G., and D. Gottlieb. 1948. The utilization of carbon compounds by some Actinomycetales as an aid for species determination. J. Bacteriol. 56:107-114.

28. Schleifer, K. H., and O. Kandler. 1972. Peptidoglycan types of bacterial cell walls and their taxonomic implications. Bacteriol. Rev. 36:407-477.

29. Sharaya, L. S., S. D. Taptykova, A. N. Pariiskaya, and L. V. Kalakoutskii. 1982. Characteristics of the life cycle of an actinomycete isolated from Alnus incana root nodules. Mikrobiologiya 51:657-663. (In Russian.)

30. Stackebrandt, E., B. Wunner-Füssl, V. J. Fowler, and K.-H. Schleifer. 1981. Deoxyribonucleic acid homologies and ribosomal ribonucleic acid similarities among sporeforming members of the order Actinomycetales. Int. J. Syst. Bacteriol. 31: $420-431$.

31. Takamiya, A., and K. Tubaki. 1956. A new form of Streptomyces capable of growing autotrophically. Arch. Mikrobiol. 25:5864. 